\title{
Environmental Ethics: Theory and Implications for Marketing
}

Raymond Benton Jr.

Loyola University Chicago, rbenton@luc.edu

Follow this and additional works at: https://ecommons.luc.edu/business_facpubs

Part of the Marketing Commons

\section{Author Manuscript}

This is a pre-publication author manuscript of the final, published article.

\section{Recommended Citation}

Benton, R. (2015). "Environmental ethics: theory and implications for marketing". In Handbook on Ethics in Marketing. Cheltenham, UK: Edward Elgar Publishing.

This Book Chapter is brought to you for free and open access by the Faculty Publications and Other Works by Department at Loyola eCommons. It has been accepted for inclusion in School of Business: Faculty Publications and Other Works by an authorized administrator of Loyola eCommons. For more information, please contact ecommons@luc.edu.

\section{c) (†) $\ominus$}

This work is licensed under a Creative Commons Attribution-Noncommercial-No Derivative Works 3.0 License. (c) Edward Elgar Publishing, 2015. 


\section{Environmental Ethics: Theory and Implications for Marketing}

Raymond Benton, Jr., Loyola University Chicago, Chicago, IL, USA

Many marketers recognize they have obligations toward the non-human world, obligations which are not fully understood. This essay sheds light on how such marketers can justify their own feelings and persuade others. The essay begins with the historical rise of environmental consciousness before discussing the two most influential of the Western ethical theories: Kantianism and utilitarianism. It then discusses their shortcomings before moving on to the sentimentalist approach to ethics that comes down to us from David Hume and Adam Smith. A direct line from the sentimentalist approach is drawn to the environmental/ecological ethics of Aldo Leopold. Much is left out of this essay; virtue ethics, social contract theory, or any of the strictly environmental philosophies that have emerged (deep ecology, ecofeminism, social ecology, bioregionalism). Neither are any of the spiritual or religious approaches to environmental ethics discussed.

If you're not depressed, I often joke to my students, it's only because you haven't been reading the newspaper. And indeed we do live in a frightening time, marked by fundamentalist violence, aggressive wars, ethnic conflict, starvation amid plenty, and the subject of this book: enormously pervasive environmental problems.

Roger S. Gottlieb, A Greener Faith: Religious Environmentalism and Our Planet's Future (2006, p. vii).

For the most part, we have cared little about our impact on the environment. The past century, and especially the past fifty years, has witnessed an increasing awareness that we can and are causing significant harm to the rest of nature. That awareness has understandably been accompanied by an increasing acceptance that we have obligations, moral obligations, toward the rest of nature. This unsettling awareness and sense of 
obligation has given rise to the sub-discipline of environmental ethics, ${ }^{1}$ or what I prefer to call ecological ethics. ${ }^{2}$

Both an awareness of and concern that we, as human beings, can and have caused harm to the rest of nature can be found as far back as the ancient Greeks (Hughes 1975; Hughes 1994; Westra and Robinson 1997). The contemporary awareness that we impact nature is often dated to 1864 and the publication of George Perkins Marsh’s Man and Nature, a second edition of which was published in 1874 with a more descriptive title: The Earth as Modified by Human Action: Man and Nature. Henry David Thoreau had already published Walden, in 1854 and John Muir was writing his books in the late 1800s and early 1900s. In 1949 Aldo Leopold’s A Sand County Almanac was published. The final chapter of A Sand County Almanac is entitled "The Land Ethic," an essay which is obligatory reading by anybody interested in the topic. Thus, in a period of about a hundred years, concerned people were raising our environmental awareness and environmental concern and urging us toward an environmental ethic.

It was not until the 1960s that concern for the environment turned into an organized and popular movement. Many consider the turning point to have been Rachel Carson's Silent Spring, published in 1962, the same year that Murray Bookchin (writing under the name Lewis Herber) published Our Synthetic Environment (1962). These were followed by economist Kenneth Boulding’s “The Economics of the Coming Spaceship Earth” (1966), Lynn White’s “The Historical Root of Our Ecological Crisis” (1967), Paul R. Ehrlich’s The Population Bomb (1968), Garret Hardin’s “Tragedy of the Commons”

\footnotetext{
${ }^{1}$ There are now many good textbooks on the subject, and some actually directed at the professions. I have listed these, and others, following the references.

2 There is precedent for this preference: see Rolston 1975; Kohák 2000; Curry 2006.
} 
(1968) and his “The Economics of Wilderness” (1969), Barry Commoner’s The Closing

Circle (1971), Dr. Seuss's The Lorax (1971), Edward Goldsmith’s Blueprint for Survival (1972), the Club of Rome's The Limits to Growth (1972) and E.F. Schumacher's Small is Beautiful (1973). Each is now considered a modern classic.

Landmark legislation also began to appear: The Clean Air Act of 1970 (based on a 1963 law), the formation of U.S. Environmental Protection Administration (1970), the Clean Water Act of 1972 (based on the 1948 Federal Water Pollution Control Act) and the Endangered Species Act of 1973. The first United Nations Conference on the Human Environment was held in Stockholm (1972). The U. N.'s World Commission on Environment and Development (W.C.E.D.) issued its report, Our Common Future, in 1987. The first Earth Summit was held in Rio (1992), followed by the Johannesburg Earth Summit (2002) and Rio+20 in 2012.

Non-governmental organizations also increased their activity during the 1960s. It 1966 David Brower and the Sierra Club placed the famous Sistine Chapel advertisements in the New York Times and other newspapers, effectively stopping, by inciting public outrage, the move to build dams that would flood the Grand Canyon (Sierra Club 2014). New groups, such as Greenpeace, Friends of the Earth, World•Watch, Earth First, Earth Island Institute, National Resource Defense Council, the Nature Conservancy and others began forming during the 1960s and 1970s. The first Earth Day was on April 22, 1970.

J. Baird Callicott taught the first environmental ethics class ever taught, anywhere in the world, in 1971 (Callicott 1987, p. vii; Lo 2009, p. 129). In 1973 the Australian philosopher, Richard Routley (later writing as Richard Sylvan), published the first paper 
on environmental ethics by a professional philosopher (Routley 1973). ${ }^{3}$ The title of his paper asked, “Is There a Need for a New, an Environmental Ethic?” In 1974 John Passmore, another Australian philosopher, published the first book-length treatment of environmental ethics, Man’s Responsibility for Nature. The first American paper on environmental ethics was by Holmes Rolston III (1975). From these beginnings emerged the philosophy sub-discipline of environmental ethics. A similar explosion in the literature occurred in religion studies, too. Two early papers were Walter Lowdermilk’s “The Eleventh Commandment,” published in 1940 and Joseph Sittler’s 1954 article, “A Theology for Earth."4

Marketing did not escape this influence. George Fisk’s Marketing and the Ecological Crisis was published in 1974 and Karl Henion’s Ecological Marketing in 1976. Michael Polonsky and Alma Mintu-Wimsatt edited a comprehensive volume, Environmental Marketing: Strategies, Practice, Theory, and Research in 1995. The first chapter of this volume addressed "Ecological Imperatives and the Role of Marketing” (Sheth and Parvatiyar 1995) and the fourth chapter proposed a "Paradigm Shift in Values to Include the Environment” (Neace 1995). More recent textbooks have used the rhetoric of sustainability to bring environmental concern to marketing. The first was perhaps Donald Fuller's Sustainable Marketing: Managerial-Ecological Issues (1999). A decade later Frank-Martin Belz and Pen Peattie published Sustainability Marketing (2009), followed by Diane Martin and John Schouten’s Sustainable Marketing (2012) and Mark Peterson’s Sustainable Enterprise: A Macromarketing Approach (2013).

3 There was one earlier but largely neglected paper entitled "Ethics and the Beetle" (MacIver 1948).

${ }^{4}$ I have also listed some of the books on religion and the environment following the references. 
These lists are incomplete: my point is not. Increasingly we are coming to understand that humans cause environmental problems and that, while some things have gotten better since the 1930s, 1940s, or 1950s, there is still cause for alarm and concern.

This contribution to the Handbook on Ethics in Marketing is for marketers with an environmental or ecological consciousness that are unsure how to talk about the moral importance of the natural environment.

\section{Philosophical Traditions}

Confucius in China, Siddhartha Gautama (the Buddha) in India and Socrates in Greece each lived at about the same time (in what is called the Axial Age, roughly five or six hundred years before the common era (BCE). Each gave rise to a historically important philosophical tradition. ${ }^{5}$ One difference between the traditions, the Eastern and the Western is that the Western tradition developed a decidedly individualistic approach to ethics (Gunn 1983) while the others made room for a consideration of the whole.

The Western philosophical tradition is concerned with human beings; indeed, with individual human beings. Only the individual human being has moral status. This position is arrived at by one of two primary routes. One is to claim that only human beings have certain special characteristics, like rationality or the ability to use language. Since only humans have these characteristics, only humans deserve moral consideration. A second route is to claim that moral relationships can only exist between reciprocating

\footnotetext{
${ }^{5}$ As in so many things, anthropologists challenge the notion that before the rise of the great philosophical traditions there was no such thing as philosophy or philosophical thinking. See, in particular, Paul Radin’s Primitive Man as Philosopher (1927).
} 
entities. Since a wolf or a wild flower cannot reciprocate, they do not warrant moral consideration from us.

Part of the challenge facing environmental ethics, then, is to find a way or ways to extend moral consideration to the rest of nature. As Patrick Curry wrote, ethical questions “can no longer be restricted to how to treat other human beings, or even animals, but must embrace the entire natural world” (2006, p. 1).

I argue for a particular approach, Aldo Leopold’s Land Ethic (1949). I do this, in part, because we can draw a direct line of descent from Adam Smith to Aldo Leopold, thereby putting Leopold squarely in the tradition upon which marketing, itself, rests. I do not believe we are ready, however, for an environmental/ecological ethic. Yet I do not despair. Victor Hugo (1802-1885) is often quoted as having written, "Nothing is more powerful than an idea whose time has come.” The time for an environmental/ecological ethic is around the corner; its time is near; its time will come. When the time is here, marketers will be ready because they will have already thought about it. They will not be caught off guard.

\section{Mainstream Ethical Theories}

Mainstream philosophical ethics tends to be one of two varieties: utilitarianism or Kantian. As applied to environmental issues, both have tried to solve environmental problems in language and concepts derived from traditional, human-centered ethics. A third thrust in the Western tradition is that of the Scottish Enlightenment, chief representatives of which include David Hume and Adam Smith. I deal first with 
utilitarianism and then with Kantianism before coming to this sentimentalist school of ethics.

\section{Utilitarianism}

Utilitarianism is likely the most familiar ethical theory to marketers because economics is thoroughly utilitarian. Marketing, related as it is to economics, is also thoroughly utilitarian. The utilitarian maxim is well known: “act so as to produce the greatest happiness for the greatest number” (Jeremy Bentham), or, alternatively, “Actions are right in proportion as they tend to promote happiness; wrong as they tend to produce the reverse of happiness” (John Stuart Mill). In both cases happiness was understood as the presence of pleasure or the absence of pain. Bentham made no distinction between higher or lower pleasures but was concerned with the sheer quantity of pleasure. Thus his quip, “The quantity of pleasure being equal, push-pin is as good as poetry.” Mill was as concerned about qualitative differences in pleasures as he was the quantity of them. His counter quip, "It is better to be a human being dissatisfied than a pig satisfied; better to be Socrates dissatisfied than a fool satisfied.”

Modern utilitarians refer to preferences and interests rather than pleasure and pain. The goal of human action becomes the maximization of welfare, understood as the maximization of preference satisfaction. People reveal their preferences through their actions and what they overwhelmingly reveal are preferences for goods and services. Accordingly, the maximization of collective satisfaction, and thereby the maximization of collective happiness, becomes the maximization of consumption. 
Utilitarianism focuses on the greatest happiness of the greatest number of human beings. Everything else is valuable only as a means to producing pleasure for us. William Baxter gave infamous expression to this when, in the context of discussing the impact of the agricultural use of DDT on animals and birds, he wrote, damage to penguins, or sugar pines, or geological marvels is...simply irrelevant...Penguins are important [only] because people enjoy seeing them walk about the rocks (1974, p. 5).

Everything central to the environmentally concerned person-animals, trees, rivers, rocks, forests, ecosystems, geological marvels-are of no value unless they serve our needs. That is a people centered ethic; it is not an environmental or ecological ethic. Lisa Newton captured this in her observation that no traditional ethic will capture our duties to nature "for the theories were all developed to treat human beings only" (2005, p. 82).

\section{Kant/Rights Theory}

The other principal ethical theory is that of Immanuel Kant. Kant argued, contrary to utilitarianism, that consequences are irrelevant to whether an action is good or bad, right or wrong. Kant would have said, Do the right thing and worry not about the consequences; let the chips fall where they may.

But what is the right thing? The rightness of an act is determined by whether the actor can honestly say that he or she would want everyone else to act in that way. If so, the action is right. If not, the action is wrong. The potential or realized consequences of the act are irrelevant. 
In Kant's view, rational people will not be prepared to adopt a rule for themselves unless they were prepared to accept it as applicable to and by all people. If I choose to act in a certain way, I must agree that I must allow others to act in a similar manner. We have a duty, an obligation, to act rationally. This has been likened to the Golden Rule: treat others the way you want them to treat you (or, in the negative, do not treat others in ways that you do not want them to treat you). The reciprocity issue can readily be seen here.

Another Kantian approach is that people should never be treated merely as a means to an end but, rather, as having ends of their own. We have ends of our own because we are rational, can think and plan for our own future. Since all else is nonrational, all else can be treated as a means to our end. As philosophers express it, people (rational beings) have intrinsic value (value in and of themselves); all else has instrumental value (value that derives from serving another's end). Or, as I believe it was Descartes that expressed it, human beings have value; everything else has a price.

To summarize, human beings deserve to be treated morally, which means they deserve to be treated as an end and not merely as a means to an end. Everything elseanimals, trees, rocks, rivers, forests, ecosystems, geological marvels—can be treated as a means to another's end. That end is our end, our purposes.

\section{Implications for Marketers}

The implications of this general thrust of traditional ethics for marketers are pretty straightforward. If we are to maximize satisfaction, happiness and pleasure, and if people reveal their preferences, through their actions in the marketplace, as preferences for 
goods and services (the output of industry), then in pursuing the good and the right, marketers have a duty to satisfy, as a marketing textbook once put it, “peoples’ desires for goods and services as they, themselves, define and express those desires” (Stanton 1981). If environmental concern is central to enough people, if people develop a preference for penguins over popcorn and petroleum, they will express that concern and those preferences through their purchases. Marketers will be listening and paying attention and will accommodate those preferences when, and if, they are expressed-but not before. This approach is woven into the very fabric of marketing theory and practice.

For those marketers with an environmental concern, this is inadequate. Even Stanton waffled toward the end of that same textbook when he wrote (1981, p. 558), In considering the marketability of a new product, marketing executives may stop asking, 'Can it be sold.' Instead, they may ask, 'Should it be sold? Is it worth the cost to society?'

As I pointed out before (Benton 1985), if marketers are to ask should something be sold, it is implied that there exists some criteria, some ethical theory, regarding human and social well-being by which we can justify that assessment. Generally people want that their actions be good and right — that they are ethical. We also want to be able to defend our actions to others. Today any such theory must include not just social well-being but the well-being of the non-human natural environment. To this point there is no theory by which marketers can ask themselves if something should be sold. All they can do, to this point, is refer to the standard refrain that it should be sold if enough people want it and will buy it. We are not to judge of the tastes and preferences of other people. 


\section{Extending Mainstream Ethical Theories}

Many have argued that the bounds of consideration should and can be extended beyond the human being. They argue that a proper understanding of utilitarianism and rights theory requires expanding the sphere of the morally considerable to include beings other than existing humans. All such efforts attempt to extend the moral community on the same basis by which we ascribe rights to humans.

\section{Suffering}

Under the guise of the original pleasure/pain principle, utilitarianism can embrace some parts of the non-human sphere since some animals can and do experience pleasure and, more especially, pain. Bentham was aware of this and advocated it because animals experience pain and the point is to maximize pleasure, which is tantamount to minimizing pain. Bentham was unconcerned about what experienced the pain: humans or hedgehogs. The point is to minimize it. As he wrote (1789):

The day may come, when the rest of the animal creation may acquire those rights which never could have been withholden from them but by the hand of tyranny. The French have already discovered that the blackness of the skin is not reason why a human being should be abandoned without redress to the caprice of a tormentor. It may come one day to be recognized that the number of the legs, the villosity of the skin, or the termination of the os sacrum, are reasons equally insufficient for abandoning a sensitive being to the same fate. What else 
is it that could trace the insuperable line? Is it the faculty of reason, or perhaps the faculty of discourse? But a full-blown horse or dog is beyond comparison a more rational, as well as more conversable animal, than an infant of a day, or a week, or even a month old. But suppose they were otherwise, what would it avail?

Bentham's first step to expanding the bounds of moral consideration, therefore, was to embrace all sensitive, or sentient, beings - those with a capacity to experience pain. The preceding passage concluded with Bentham’s perhaps most quoted passage: ‘The question is not, Can they reason? Nor, Can they talk? But, Can they suffer' (the emphasis is Bentham’s).

Despite the fact that Bentham explicitly argued that animal suffering should be included in the utilitarian calculus, in practice mainstream utilitarians have only considered human pleasure and human pain. Including the suffering of others significantly alters the calculations, as Lisa Newton clearly pointed out (2005, p. 82):

Utilitarianism, the only philosophy that truly supports rights for non-human animals, asks that we seek the greatest happiness of the greatest number in the long run. Happiness of what? The costs and benefits of whaling come out very differently if you count the happiness of the whales into the equation.

Peter Singer was among the first to forcefully include animal suffering in the utilitarian calculus. In Animal Liberation (1975) he argued, as did Bentham, that any being capable of suffering has an interest in avoiding suffering and that any being with interests deserves to have those interest taken into account by others with similar 
interests. Pain is pain no matter what experiences it-people, penguins or possums. The interests of all sentient beings should receive consideration in our utilitarian calculations.

The problem, however, lies in drawing the boundary. What is a sentient being? Humans, certainly. Horses, too. But where do we stop? Line them up: deer, wolves, coyotes, rabbits, rats, birds, snakes, fish, worms, snails, slugs, bugs, bacteria, viruses, trees, meadows, rivers. On the basis of pain and suffering, where do we draw the line? What do we include and what do we exclude from the moral community?

\section{Sentience}

When most people read or hear the word sentient they likely think of pain and suffering. Sentient, however, has a more general meaning: to be conscious of something (and not only of pain and suffering). Working from this wider meaning of the word sentient, there are at least two attempts to extend moral consideration within standard Western ethical philosophy (see Varner 2001).

Moral rights function to protect interests. In order to have rights, an entity must be able to consciously aim at - to think about-its own interests. To do so presupposes at least rudimentary cognitive abilities. We now know that not all non-human animals lack rationality, if by that we mean an ability to solve practical problems in a logical, if rudimentary, way (Griffin 2001; Morell 2013; Wasserman and Zentall 2006; Woods 2010). Therefore, because they share with us at least some of the characteristics by which we ascribe rights to ourselves they, too, deserve moral consideration. Logical consistency 
requires us to ascribe rights to at least some animals, too. Trees, plants, rocks and rivers are excluded because of they lack cognitive abilities.

A second approach attempts to include at least trees and plants. This approach accepts that for all living things there are conditions that are good for them and conditions that are bad for them. Hence, all living things have a good of their own and, therefore, all living things have interests (an interest in living) and therefore deserve moral consideration.

Albert Schweitzer (1929) is one of the early proponents of this sort of view. He reported having a profoundly moving experience watching four hippopotamuses and their young plod along. This experience led him to see that all life possesses the same will-tolive that every human being possesses. Once we recognize that all life has the same willto-live that we find in ourselves and in other people, we will see that morality requires that all life be respected, not just human life. Schweitzer argued for what he called 'reverence for life’ ethic.

\section{Summary and Implications}

Because of Singer’s (1975) and Regan’s (1983) persuasively argued views we now scrutinize factory farming and have eliminated some animal testing. They extended the boundaries of the moral community to include not just humans but all those with at least some of the characteristic by which we ascribe rights to ourselves - the capacity to experience pain or at least some level of cognitive capacity or having an interest in 
continuing to live. They have drawn attention to their moral right to be free from human induced pain and suffering, and their moral right to life.

Each of these extensions expands the moral community, yet much remains left out because of the necessity of drawing boundaries. In addition, both emphasize, to the exclusion of all else, the individual—the individual person, the individual animal, the individual tree (Gunn 1983, Marietta 1993). Left out, even from these extended versions, are species preservation, air and water pollution, and ecosystem integrity-just those things that are centrally important to those with environmental concerns. In none of these extended views are species or ecosystems candidates for moral standing. It is this basic feature of traditional ethics, Varner notes, that "has played a major role in their rejection by many prominent environmental ethicists” (Varner 2001, p. 195).

Despite these limitations, even these extensions have important implications for marketers and for marketing educators. For example, when conducting an environmental scan it is not enough to consider only the social, economic, technological, competitive and regulatory environments — the now standard elements of the marketing environment. To assess the opportunities and threats to an organization, marketers must now add, as a new element in the marketing environment, at least some elements in the non-human natural environment. Marketers must not ask simply how the non-human natural environment impacts them or their organization, but how they and their organization impact the living beings that comprise the non-human natural environment. When marketers do that, they may come up with a different answer to the question, "Should it be sold.” Marketers might also find that they are not compelled to always take their marching orders from the consumer. 
To do this, however, the standard sequence in most marketing textbooks must be revised. The chapter on marketing ethics, which often follows the chapter on conducting a marketing scan, will have to come first. The reasons why marketers should consider the non-human natural environment must be explained before students receive instruction in conducting the marketing scan. And, of course, the standard textbook treatment of marketing ethics will have to be expanded beyond the utilitarian atomistic and chauvinistic social philosophy in which marketing ethics are embedded.

\section{An Evolutionary Approach to Ethics Based on Sentiments}

Most Western moral philosophy—utilitarianism, rights theory, social contract theory-accepts our ability to reason is the source and origin of ethics. At some time in the past people decided it was better to establish codes for ethical behavior — to accept a limitation on human freedom — than to continue in the proverbial Hobbesian war of all against all.

The problem with this account of the origin of ethics is that it has the cart before the horse. Our ability to reason cannot possibly have evolved apart from an intensely social context, and such a context—nay, society, itself—cannot possibly have existed in the absence of some moral restraints, some limitations on freedom of action in the so called struggle for existence. Something, civil law or codes of proper conduct, had to already exist to hold the society together. ${ }^{6}$

${ }^{6}$ In anthropology there has been a parallel discussion regarding the origins of culture. The classic account held that there was a critical point in the evolution of Homo sapiens when culture was added on to a completed or nearly completed biological being. At this 
If our ability to reason is not the source and origin of ethics and morality, from whence do they come? David Hume, Adam Smith and others- those that make up the Scottish Enlightenment-located the source and origin of morality not in reason but in sentiments, in fellow feeling, sympathy, benevolence, affection, generosity. Hence the title of Adam Smith's first book, Theory of Moral Sentiments. ${ }^{7}$

David Hume declared, in A Treatise of Human Nature (originally published in 1739-1740), ${ }^{8}$ reason is not a motive to human action—neither right actions nor wrong actions. Rather, “moral good and evil are ... distinguish'd by our sentiments, not by reason” (1978, p. 589, emphasis in the original). Human actions, both good and bad, are motivated by other-oriented sentiments: sympathy, fellow feeling and benevolence. These are just as much a part of the human psychological constitution as are the selforiented sentiments of greed and lust. As Callicott (1982, p. 167) explained Hume’s views,

The moral sentiments are both natural and universally distributed among human beings...In other words, like physical features — the placement of the eyes in the

critical point biological evolution stopped (or nearly stopped) and cultural evolution took over. The problem is that the archaeological record suggests that such a moment never occurred and that rather than sequential development it was a co-evolutionary development of the biological and the cultural (see Geertz 1973, pp. 61-69).

7 The Theory of Moral Sentiments was first published in 1759 and went through six editions, the last of which was published in 1790. Smith's other book, An Inquiry into the Nature and Causes of the Wealth of Nations, was first published in 1776 and went through five editions, the last of which was in 1789, the year before the sixth edition of the Theory of Moral Sentiments. Smith died in 1790.

${ }^{8}$ A Treatise of Human Nature consists of three books. The first two were published in 1739. Book III was published in 1740. 
head, two arms, two legs an opposed thumb, etc. - the moral sentiments are only slightly variable psychological features common to all people.

Just as people have similar yet slightly variable physical features, so, too, "the moral sentiments are only slightly variable psychological features common to all people.” And just as there are physically "freakish or maimed" people, so, too, "there may be people who, because of congenital defect or the vagaries of life, are lacking one, several, or all of the moral sentiments to one degree or another."

Hume was unconcerned with the origins of ethics. He simply claimed that the moral sentiments are natural, universal and fixed psychological characteristics of human nature (Callicott 1982). Charles Darwin, however, was interested in the origins of ethics and morality and he relied on Hume, Smith and Bain for his evolutionary psychology. ${ }^{9}$ Callicott (p. 165) states, “no other available analysis of morals than Hume’s would have been useful to Darwin” and, Antony Flew notes (1967, p. 59), Hume’s approach to moral questions "might almost seem to demand an evolutionary background."

Darwin's argument in the third chapter of The Descent of $\mathrm{Man}^{10}$ was that (quoting Callicott) "the moral sentiments (fellow feeling, sympathy, benevolence, affection, generosity) ... co-evolved with the evolution of protohuman societies. On the subject of “the all-important emotion of sympathy” Darwin (1871, p. 81) writes:

${ }^{9}$ Charles Darwin is most known for On the Origin of Species (1859). He also published The Descent of Man (1871). The third chapter of The Descent of Man discusses the issue of the origins and functions of morality.

${ }^{10}$ I use a reprint of the first edition (1871). In the second edition of The Descent of Man this is chapter four. In both editions the chapter is entitled "Comparison of the Mental Powers of Man and the Lower Animals_continued." It is in this chapter that Darwin references David Hume's An Enquiry Concerning the Principles of Morals (1751), Adam Smith's Theory of Moral Sentiments (1759), and Alexander Bain's Mental and Moral Science (1868). 
In however complex a manner this feeling may have originated, as it is one of high importance to all those animals which aid and defend one another, it will have been increased through natural selection; for those communities, which included the greatest number of sympathetic members, would flourish best, and rear the greatest number of offspring. (1871, p. 82)

The moral sentiments, in short, have survival value. As Darwin expressed it (1871, p. 93), No tribe could hold together if murder, robbery, treachery, etc., were common; consequently such crimes within the limits of the same tribe 'are branded with everlasting infamy;' but excite no such sentiment beyond these limits.

Similarly, regarding truth telling Darwin wrote (1871, p. 95),

There cannot be fidelity without truth; and this fundamental virtue is not rare between the members of the same tribe...; but to lie to your enemy has rarely been thought a sin, as the history of modern diplomacy too plainly shews [sic]. Darwin concludes (1871, pp. 96-97), actions are regarded by savages, and were probably so regarded by primeval man, as good or bad, solely as they affected in an obvious manner the welfare of the tribe,- - not that of the species, nor that of man as an individual member of the tribe.

Hume does not abandon reason; its role is to guide the passions. Reason guides our passions and sentiments in two ways. First, it excites a passion by informing us of the existence of something that is the proper object of the passion. Second, it discovers the connections of causes and effects, thereby providing us the means of exerting a passion. But it is our feelings, our sentiments, which serve as the ultimate foundation of our moral 
judgments. Distinctions of good and evil, vice and virtue are founded not on reason but upon sentiment. Reason supports ethical behavior by discerning the proper objects of our other-oriented moral sentiments and by discerning the complex relations of cause and effect.

For Hume the condition of humankind in the absence of civilization is not a war of all against all. It is a condition in which people, even protohumans, care for perhaps a small circle of friends and cooperate with them. But it is also a world in which selfinterest and preference for these friends over strangers makes wider cooperation difficult—but not impossible. Again, Darwin (1871, p. 100-101):

As man advances in civilization, and small tribes are united into larger communities, the simplest reason would tell each individual that he ought to extend his social instincts and sympathies to all the members of the same nation, though personally unknown to him. This point being once reached, there is only an artificial barrier to prevent his sympathies extending to the men of all nations and races. If, indeed, such men are separated from him by great differences in appearance or habits, experience unfortunately shews [sic] us how long it is before we look at them as our fellow-creatures. Sympathy beyond the confines of man, that is humanity to the lower animals, seems to be one of the latest moral acquisitions. ... This virtue, one of the noblest with which man is endowed, seems to arise incidentally from our sympathies becoming more tender and more widely diffused, until they are extended to all sentient beings. ${ }^{11}$

\footnotetext{
${ }^{11}$ It bears noting the similarity here between Bentham and Darwin and pointing out a crucial difference. To Bentham extending moral consideration, a sense of kinship, to all
} 
The evolutionary and developmental thrust of Darwin’s thinking about morals is evident. Hume's thesis, which lies at the heart of Darwin's consideration of the origins and development of ethics, is that at the center and base of morality lies our natural tendency to love, care and have sympathy for others and that this is possible because the human being is fundamentally and simultaneously a loving, parochial and selfish being.

\section{Aldo Leopold and the Land Ethic}

Aldo Leopold was not a philosopher, nor was he fully an academic, although in later life he did have a position at the University of Wisconsin. He was, rather, a longtime employee of the U.S. Department of Forestry. Nevertheless, he is referred to as 'the father of contemporary environmental ethics’ (Callicott 1982, p. 164) and his book A Sand County Almanac is referred to as 'the bible of the modern conservation movement' (Callicott 1987, p. 3).

Leopold, a natural scientist, follows Darwin's account of the origin and evolution of ethics. Leopold writes (1949, p. 109),

It is a century now since Darwin gave us the first glimpse of the origin of species. We know now what was unknown to all the preceding caravan of generations: that men are only fellow-voyagers with other creatures in the odyssey of evolution. This new knowledge should have given us by this time a sense of kinship with follow-creatures; a wish to live and let live; a sense of wonder over the magnitude and duration of the biotic enterprise. 
In the passage quoted above Darwin permits that sympathy can be extended 'beyond the confines of man' to include 'the lower animals' and that this seems to him, to Darwin, to be 'one of the latest moral acquisitions.' Darwin did not propose that any such extension end at this point; he proposed only that it is 'one of the latest' extensions. Leopold's Land Ethic, to quote Leopold now, 'simply enlarges the boundary of the community to include soils, waters, plants, and animals, or collectively: the land’ (1949, p. 204).

The implication of this extension is that a land ethic 'changes the role of Homo sapiens from conqueror of the land-community to plain member and citizen of it' (1949, p. 204). This, in turn, implies 'respect for his fellow-members, and also respect for the community as such’ (1949, p. 204). Leopold insists only that the term community (our community) include among its referents the non-human natural entities_-'soils, waters, plants, and animals’ (1949, p. 204).

This is a significant break with the Western tradition. It is not simply a prudential extension of a utilitarian version of environmental ethics. It is capturing a reverence-forlife ethic but in holistic way. The reverence-for-life ethic associated with Schweitzer (1923), Goodpaster (1978) and Taylor (1986) is an individualistic ethic. In the hands of Leopold it is a holistic ethic.

\section{A Living Thing}

Our dominant way of looking at the world is mechanistic (Merchant 1980, 1998, 2006, 2008a, 2008b; Kinsley 1995, Chapter 10; Descartes). We do not always appreciate the degree and the extent to which we are imprisoned by this metaphor. In Metaphysic of 
Ethics Kant writes, 'man has no duties imposed upon him, except those owed by him to humanity' and that 'Mankind can ... have no duty toward any being other than his fellow-men,' continuing, 'In regard of the BEAUTIFUL [sic] but lifeless objects in nature ...' (1986, p. 258-260). This passage is part of a discussion of why it is wrong, aesthetically, to wantonly destroy non-human nature. The point here, however, is the unquestioned acceptance that everything other than the animated is, however beautiful, lifeless.

Leopold writes that it is inconceivable that 'an ethical relation to land can exist without love, respect, and admiration for land, and a high regard for its value' (1949, p. 223), by which Leopold meant intrinsic and not simply instrumental value. How can one love the lifeless? If the biotic community is to be loved, one must emancipate oneself from the mechanical metaphor, indeed a very difficult task. It is a task Leopold accomplished for himself.

In a 1920s essay that remained unpublished until 1979, Leopold explains our ethical issue in characteristic brevity and clarity (Leopold 1979, all quotations are from pages 138-139). He begins, 'A false front of exclusively economic determinism is so habitual to Americans in discussing public questions that one must speak in the language of compound interest to get a hearing.' He goes on to say, 'In past and more outspoken days conservation was put in terms of decency rather than dollars,' and then quotes Ezekiel: 
Seemeth it a small thing unto you to have fed upon good pasture, but ye must tread down with your feet the residue of your pasture? And to have drunk of the clear waters, but ye must foul the residue with your feet?

Leopold suggests that in these two sentences 'may be found an epitome of the moral question involved,' further commenting, 'It is possible that Ezekiel respected the soil, not only as a craftsman respects his material, but as a moral being respects a living thing.'

Aware of the pitfalls of language, Leopold continued: 'The very words living thing have an inherited and arbitrary meaning derived not from reality, but from human perceptions of human affairs.' He then tackles our inherited and arbitrary perception of an inanimate, mechanistic nature by quoting the philosopher Ouspensky (1922):

Were we to observe, from the inside, one cubic centimeter of the human body, knowing nothing of the existence of the entire body and of man himself, then the phenomena going on in this little cube of flesh would seem like elemental phenomena in inanimate nature.

Leopold then indicates that Ouspensky suggested, quoting Leopold now,

[I]t is at least not impossible to regard the earth’s parts—soil, mountains, rivers, atmosphere, etc.- - as organs, of parts of organs, or a coordinated whole, each part of a definite function. And, if we could see this whole, as a whole, through a great period of time, we might perceive not only organs with coordinated functions, but possibly also that process of consumption and replacement which in biology we call the metabolism, or growth. In such a case we would have all the visible attributes of a living thing, which we do not now realize to be such because it is too big, and its life processes too slow. And there would also follow 
that invisible attribute—a soul, or consciousness — which not only Onpensky

[sic], but many philosophers of all ages, ascribe to all living things and

aggregations thereof, including the "dead” earth.

In short, the moral issue to Leopold is that we approach conservation from a strictly economic point of view—and that our economic (as well as scientific) point of view rests, in turn, on a perception of the other-than-human as mechanistic, inanimate and lifeless. Leopold was of the same voice as Hans Jonas who wrote (1984, p. 8), 'We should keep ourselves open to the thought that natural science may not tell the whole story about Nature.' Leopold does not, to my recollection, say that the Land Ethic requires acceptance that the other-than-human world is a living thing. Accepting that the earth might be a living entity may be necessary for developing a genuine and deep 'love and respect' for it. ${ }^{12}$

Just as utilitarianism has its maxim (the greatest good for the greatest number) and Kantian ethics has its maxim (act in such a way that you can will that your actions should become a universal law), Leopold, too, distilled a general maxim, an overarching imperative, as a guide to conduct in respect to the environment (1949, p. 224-225):

A thing is right when it tends to preserve the integrity, stability, and beauty of the biotic community. It is wrong when it tends to do otherwise.

This maxim is presented in the context of Leopold's discussion of the obstacles that lie in the way of developing a Land Ethic. Chief among those obstacles, 'the 'key-log' which must be moved,' is our habit of 'thinking about decent land-use as solely an economic

12 The parallels here with James Lovelock's Gaia Hypothesis, or Gaia Theory, have not escaped me. See Lovelock 1987, 2006, 2010; Primaves 2000; and especially Aram 1996, Jones 1996, Rawles 1996, Sahtouris 1996). 
problem.' Economics determines, in a limiting way, what can be done for land. 'It always has and it always will.' The fallacy that 'economic determinists have tied around our collective neck, and which we now need to cast off, is the belief that economics determines all land-use. This is simply not true.' As Leopold states it (1949, p. 214), a system of conservation based solely on economic self-interest is hopelessly lopsided. It tends to ignore, and thus eventually to eliminate, many elements in the land community that lack commercial value, but that are (as far as we know) essential to its healthy functioning. It assumes, falsely, I think, that the economic parts of the biotic clock will function without the uneconomic parts.

To apply this maxim, to know what preserves and what disrupts the integrity, stability and beauty of a biotic community, requires some degree of ecological literacy, something we do not now have—a point that Leopold, himself, observed and considered to be another major impediment to the evolution of a land ethic.

\section{An Example and Implications for Marketers}

Leopold's Land Ethic is opposed to our contemporary push to make the business case for sustainability (to use a contemporary term). Leopold was concerned about this. In the 1920s piece cited above he wrote, 'one must speak in the language of compound interest to get a hearing.' In other words, one must make the business case to get a hearing. Leopold also addressed this issue in 'The Land Ethic.' Under the heading 'Substitutes for a Land Ethic' (pp. 210-212) he discusses the 'weakness in a conservation system based wholly on economic motives.' Simply, it is that 'most members of the land 
community have no economic value.' He suggests that of the '22,000 higher plants and animals native to Wisconsin, it is doubtful whether more than 5 per cent can be sold, fed, eaten, or otherwise put to economic use. Yet these creatures are members of the biotic community and if (as I believe) its stability depends on its integrity, they are entitled to continuance.'

He then discusses wildflowers, songbirds, predatory mammals, raptorial birds, fish-eating birds, certain species of trees and entire biotic communities (marshes, bogs, dunes and deserts). He makes the same point for each: to save them we invent subterfuges to give them economic importance. In the example of songbirds he writes, At the beginning of the century songbirds were supposed to be disappearing. Ornithologists jumped to the rescue with some distinctly shaky evidence to the effect that insects would eat us up if birds failed to control them. The evidence had to be economic in order to be valid.

If we had a land ethic, an environmental ethic, we would have extended to wildflowers, songbirds, predatory mammals and the rest 'as a matter of biotic right,' the right to simply exist—regardless of the presence or absence of economic advantage to us.

Consider now the contemporary case of the Pacific yew (Taxus brevifoliai), a tree that grows primarily in California, Oregon and Washington (New York Times 1987; Egan 1991; Kolata 1991; Hanson 1992, Gersmann and Aldred 2011, Kilham 2013). It is related to species in England, Western Europe, Russia, China, Japan, Afghanistan, India and Pakistan. Of all these species, the Pacific yew is the largest.

It is also one of the slowest growing trees in the world-growing at less than onetenth the rate of the Douglas fir, under the shade of which the Pacific yew grows. The 
Forest Service classifies the Pacific yew as a weed tree with no value. As such it was typically destroyed as part of traditional clear-cutting forestry practices. After ripping out the yews and all other non-commercial trees in a section, loggers would place them in piles of brush and burn them.

It is not considered endangered species, so why do we talk about this worthless weed tree today? Because in 1961 we discovered it was a potential source of naturally occurring compound that might be used to treat cancer, particularly ovarian cancer and possibly lung cancer. In 1979 it was discovered how the compound, taxol, worked to kill cancer cells and in 1989 it was figured out how to make it soluble (which was necessary to administer it). Promising clinical results then followed. The problem is that it takes six 100-year-old Pacific yews to treat one patient.

Today the business case for the Pacific yew is easy to make. We recognize its potential medicinal uses, its health benefits—and probable profits to be earned. But how would we have made the business case for the Pacific yew in 1960? And how do we make the business case now for the other non-commercial trees ripped out and burned with the yew? If we focused not on the individual trees but on the biotic community as such, and if we gave that biotic community, to which we also belong, the right to exist, we would not have been wantonly burning the yew and other weeds trees just because they had no commercial value.

To return to Aldo Leopold (p. 213), 
There is a clear tendency in American conservation ${ }^{13}$ to relegate to government all necessary jobs that private land-owners fail to perform. ... Industrial landowners and users, especially lumbermen and stockmen, are inclined to wail long and loudly about the extension of government ownership and regulation to land, but (with notable exceptions) they show little disposition to develop the only visible alternative; the voluntary practice of conservation on their own lands.

Of the farmer he wrote, 'we asked the farmer to do what he conveniently could to save his soil, and he has done just that, and only that’ (p. 209). We have not told the farmer the magnitude of his obligations.

Obligations have no meaning without conscience, and the problem we face is the extension of the social conscience from people to land. ... No important change in ethics was ever accomplished without an internal change in our intellectual emphasis, loyalties, affections, and convictions. (pp. 209-210). What Leopold says of the farmer we could, and should, say of business today: we have obligations and those obligations have no meaning without conscience. The challenge for marketers is to extend the social conscience from people to the rest of the biotic community.

As conceived by Leopold the land ethic is not about preserving everything in its natural state. It is not about preventing the use of resources (natural capital). He wrote (p. 204),

${ }^{13}$ Leopold's concept of conservation is not too far removed from some meanings of our word sustainability. Conservation, he wrote, is our effort to understand and preserve "the capacity of the land for self-renewal (p. 221). 
A land ethic of course cannot prevent the alteration, management, and use of these 'resources,' but it does affirm their right to continued existence, and, at least in spots, their continued existence in a natural state.

\section{Conclusions}

As I stated above, I do not believe we are ready for an environmental ethic, an ethic that embraces, respects and gives moral consideration to everything and not simply to human beings or to sentient animals. In the meantime, and until we are, we can at least go part way and give moral consideration to some aspects and some components of the non-human natural environment.

Using any of these extended theories for making decisions that impact the environment—and all decisions impact the environment—is far better than not caring about the environment at all or continuing with the presumption that non-human nature is so grand, so huge, that nothing we can have a negative impact. It is, after all, our life support system. Whatever extensionist ethic one is most comfortable accepting, realize that whichever approach one adopts it has deficiencies and difficulties. One must realize, too, that its validity cannot be convincingly demonstrated to those who begin from different presumptions and assumptions.

I leave many questions unanswered. This is in part because of space constraints. It is also because I do not have the answers. The present course of environmental destruction and all its attendant ills is so great that every intellectual tradition, the religious and the secular, is today searching for another approach, one consistent with its 
own tradition, to understanding and recasting the relationship between the human and the non-human. Leopold's Land Ethic is not necessarily the one and only solution. It does, however, give an idea of what an environmental/ecological ethic might look like. And it does connect with the Enlightenment tradition, something Hinchman and Hinchman (2001) have argued is important in and of itself. Finally, Leopold's Land Ethic also connects to the specific socio-economic tradition of which marketing is a part, the one emanating from Adam Smith and the Scottish Enlightenment. In the end, Lynn White (1967) might well have been correct that the environmental crisis is, at root, a spiritual crisis. To this Leopold would agree.

I began with a passage from Roger S. Gottlieb’s A Greener Faith: Religious Environmentalism and Our Planet's Future (2006). I end with a thought from E.B. White (2006):

I would feel more optimistic about a bright future for man if he spent less time proving he can outwit Nature and more time tasting her sweetness and respecting her seniority.

To this Leopold would also agree.

\section{References}

Abram, David (1996), “The Mechanical and the Organic: Epistemological Consequences of the Gain Hypothesis,” in Gaia in Action: Science of the Living Earth edited by Peter Bunyard. Edinburgh: Floris Books.

Bain, Alexander (1868), Mental and Moral Science. London: Longmans, Green and Co. 
Baxter, William F. (1974), People or Penguins: The Case for Optimal Pollution (New York: Columbia University Press).

Belz, Frank-Martin and Ken Peattie (2009), Sustainability Marketing: A Global Perspective. John Wiley \& Sons.

Bentham, Jeremy (1789), Introduction to the Principles of Morals and Legislation, Chapter 17, Section 1, footnote to paragraph 4.

Benton, Raymond, Jr. (1985), “Alternative Approaches to Consumer Behavior,” in Research in Marketing: Changing the Course of Marketing: Alternative Paradigms for Widening Marketing Theory, edited by Nikhilkesh Dholakia and Johan Arndt. Greenwich, CT: Jai Press, Inc.

Bookchin, Murray (1962) (writing under the name Lewis Herber), Our Synthetic Environment. New York: Alfred A. Knopf.

Boulding, Kenneth E. (1966), The Economics of the Coming Spaceship Earth, in H. Jarrett (ed.), Environmental Quality in a Growing Economy. Baltimore, MD: Resources for the Future/Johns Hopkins University Press (pp. 3-14). Callicott, J. Baird (1982), “Hume’s Is/Ought Dichotomy and the Relation of Ecology to Leopold’s Land Ethic,” Environmental Ethics 4 (): 163-174. , editor (1987), Companion to A Sand County Almanac: Interpretive \&

Critical Essays. Madison, Wisconsin: University of Wisconsin Press.

Carson, Rachel (1962), Silent Spring. New York: Houghton Mifflin

Commoner, Barry (1971), The Closing Circle: Nature, Man, and Technology. New York: Knopf. 
Curry, Patrick (2006), Ecological Ethics: An Introduction. Cambridge, U.K.: Polity Press.

Darwin, Charles (1981, originally 1871), The Descent of Man, and Selection in Relation to Sex, with an introduction by J.T. Bonner and R.M. May. Princeton, NJ: Princeton University Press.

Descartes, René (1993), “Animals are Machines,” in Environmental Ethics: Divergence and Convergence, edited by Susan J. Armstrong and Richard G. Boltler. New York: McGraw-Hill.

Egan, Timothy (1991), “Carving Out a Market for Oregon’s Yew Tree,” New York Times (May 31). http://www.nytimes.com/1991/05/31/us/carving-out-a-marketing-fororegon-s-yew-tree.htm (accessed on February 7, 2014).

Ehrlich, Paul R. (1971), The Population Bomb. Buccaneer Books.

Fisk, George (1974), Marketing and the Ecological Crisis. New York: Harper \& Row. Flew, Anthony (1967), Evolutionary Ethics. London: Macmillan.

Fuller, Donald A. (1999), Sustainable Marketing: Managerial-Ecological Issues. Thousand Oaks, California: Sage Publications.

Geertz, Clifford (1973), “The Growth of Culture and the Evolution of Mind,” Chapter 3 in The Interpretation of Cultures. New York: Basic Books, Inc.

Gersmann, Hanna and Jessica Aldred (2011), “Medicinal Tree Used in Chemotherapy Drug Faces Extinction,” The Guardian (9 November) accessed at http://www.theguardian.com/environment/2011/nov/10/iucn-red-list-treechemotherapy)

Goldsmith, Edward (1972), Blueprint for Survival. Penguin Books. 
Goodpaster, Kenneth (1978), “On Being Morally Considerable,” Journal of Philosophy 75: 308-325.

Gottlieb, Roger S. (2006), A Greener Faith: Religious Environmentalism and Our Planet's Future. NY: Oxford University Press.

Griffin, Donald R. (2001), Animal Minds: Beyond Cognition to Consciousness. Chicago: University of Chicago Press.

Gunn, Alastair S. (1983), “Traditional Ethics and the Moral Status of Animals,” Environmental Ethics 5 (2): 133-154.

Hanson, Betsy (1992), “Yews in Trouble,” Discover 13 (January): 55. Hardin, Garrett (1968), “The Tragedy of the Commons,” Science 162 (Dec): pp. 12431248. (1969), “The Economics of Wilderness,” Natural History 78(6): pp. 20-27. Henion, Karl E. II (1976), Ecological Marketing. Columbus, Ohio: Grid.

Hinchman, L. P. \& Hinchman, S. K. (2001), “Should Environmentalists Reject the Enlightenment?” The Review of Politics 63 (4): 663-692.

Sierra Club (2014), “David Brower (1912-2000): Grand Canyon Battle Ads,” (http://content.sierraclub.org/brower/grand-canyon-ads/) (accessed July 12, 2014). Kilham, Chris (2013), “Pacific Yew: A Potent Cancer Fighting Agent,” FoxNews.com (http://www.foxnews.com/health/2013/08/21/pacific-yew-potent-cancer-fightingagent/) (accessed on February 7, 2013).

Hughes, J. Donald (1975), Ecology in Ancient Civilizations. Albuquerque, NM: University of New Mexico Press. 
(1994), Pan's Travail: Environmental Problems of the Ancient Greeks and Romans.

Hume, David (1978, originally 1739), A Treatise of Human Nature, second edition, P.H. Nidditch (ed.). Oxford: Clarendon Press.

Jonas, Hans (1984), The Imperative of Responsibility: In Search of an Ethics for the Technological Age. Chicago: University of Chicago Press.

Jones, Alwyn K. (1996), “A Gaian Critique of Contemporary Social Theory,” in Gaia in Action: Science of the Living Earth edited by Peter Bunyard. Edinburgh: Floris Books.

Kant, Immanuel (1886), The Metaphysic of Ethics, $3^{\text {rd }}$ edition, trans. by J.W. Semple, ed. with Introduction by Rev. Henry Calderwood. Edinburgh: T. \& T. Clark.

Kilham, Chris (2013), “Pacific Yew: A Potent Cancer Fighting Agent,” FoxNews.com (http://www.foxnews.com/health/2013/08/21/pacific-yew-potent-cancer-fightingagent/) (accessed on February 7, 2013).

Kinsley, David (1995), Ecology and Religion: Ecological spirituality in Cross-Cultural Perspective. Englewood Cliffs, NJ: Prentice Hall.

Kohák, Erazim (2000), The Green Halo: A Bird's Eye View of Ecological Ethics. Open Court Publishing Company.

Kolata, Gina (1991), “Tree Yields a Cancer Treatment, But Ecological Cost May Be High,” New York Times May 13 (accessed at http://www.nytimes.com/1991/05/13/us/tree-yields-a-cancer-treatment-butecological-cost-may-be-high.html on February 5, 2014)

Leopold, Aldo (1949), A Sand County Almanac. New York: Oxford University Press. 
(1979), "Some Fundamentals of Conservation in the Southwest,"

Environmental Ethics 1 (Summer): 131-141.

Lo, Y. S. (2009), "Callicott, J. Baird 1941-." Encyclopedia of Environmental Ethics and Philosophy. Ed. J. Baird Callicott and Robert Frodeman. Vol. 1. Detroit: Macmillan Reference USA.

Lovelock, James (1987), Gaia: A New Look at Life on Earth. New York: Oxford University Press. (2006) The Revenge of Gaia: Earth's Climate in Crisis and the Fate of Humanity. New York: Basic Books. (2010), The Vanishing Face of Gaia: a Final Warning. New York: Basic Books.

Lowdermilk, Walter C. (1940), “The Eleventh Commandment,” American Forests 46 (January): 12-15.

MacIver, A.M. (1948), “Ethics and the Beetle,” Analysis 8 (5): 65-70.

Marietta, Don E. (1993), “Environmentalism and Individuals,” in Environmental Ethics: Divergence and Convergence, second edition edited by Susan Armstrong and Richard Botzler. Boston: McGraw-Hill.

Marsh, George Perkins (1864), Man and Nature; or, Physical Geography as Modified by Human Action. New York: Charles Scribner (1874), The Earth as Modified by Human Action: Man and Nature. New York: Scribner, Armstrong \& Co. Martin, Diane and John Schouten (2012), Sustainable Marketing. Prentice Hall. 
Meadows, Donella, Dennis L. Meadows, Jørgen Randers and William W Behrens III (1972), The Limits to Growth: A Report for The Cub of Rome's Project on the Predicament of Mankind. New York: Universe Books.

Merchant, Carolyn (1980), The Death of Nature: Women, Ecology and the Scientific Revolution. San Francisco: Harper \& Row. (1998), “The Death of Nature: A Retrospective,” Organization \& Environment 11(2): 198-206. (2006), “The Scientific Revolution and The Death of Nature,” Isis 97: 513533. (2008a), “Secrets of Nature: The Bacon Debates Revisited,” Journal of the History of Ideas 69 (1): 147-162. (2008b), “The Violence of Impediments: Francis Bacon and the Origins of Experimentation,” Isis 99: 731-760.

Morell, Virginia (2013), Animal Wise: the Thoughts and Emotions of Our Fellow Creatures. New York: Random House.

Neace, M. Bill (1995), “Marketing’s Linear-Hierarchical Underpinnings and a Proposal for a Paradigm Shift in Values to Include the Environment,” Chapter 4 in Environmental Marketing: Strategies, Practice, Theory, and Research edited by Michael J. Polonsky and Alma T. Mintu-Wimsatt. Binghamton, NY: The Haworth Press.

New York Times (1987), “Demand for Yew Tree Concerns Environmentalists,” May 3 (accessed at http://www.nytimes.com/1987/05/03/demand-for-yew-tree-concernsenvironmentalists.html on February 6, 2014) 
Newton, Lisa H. (2005), Business Ethics and the Natural Environment. Malden, Massachusetts: Blackwell Publishing.

Ouspensky, P.D. (1922) Tertium Organum, second American edition. New York: Alfred A. Knopf.

Passmore, John (1974), Man's Responsibility for Nature: Ecological Problems and Western Traditions. Gerald Duckworth \& Co.

Peterson, Mark (2013), Sustainable Enterprise: A Macromarketing Approach. Sage Publications.

Polonsky, Michael J. and Alma T. Mintu-Wimsatt, editors, (1995), Environmental Marketing: Strategies, Practice, Theory, and Research. Binghamton, NY: The Haworth Press.

Primavesi, Anne (2000), Sacred Gaia: Holistic Theology and Earth System Science. New York: Routledge.

Radin, Paul (1927), Primitive Man as Philosopher. New York: D. Appleton Co. Rawles, Kate (1996), “Ethical Implications of the Gaia Theory,” in Gaia in Action: Science of the Living Earth edited by Peter Bunyard. Edinburgh: Floris Books. Regan, Tom (1983), The Case for Animal Rights. Berkeley, CA: University of California Press.

Rolston III, Holmes (1975), “Is there an Ecological Ethic?” Ethics: An International Journal of Social, Political, and Legal Philosophy 18 (2): 93-109.

Routley, Richard (1973), “Is there a Need for a New, an Environmental Ethic?” Proceedings of the XV World Congress on Philosophy, pp. 205-210. 
Sahtouris, Elisabet (1996), “The Gaia Controversy: a Case for the Earth as an Evolving Organism," in Gaia in Action: Science of the Living Earth edited by Peter Bunyard. Edinburgh: Floris Books.

Schumacher, E.F. (1973), Small is Beautiful: Economics as if People Mattered. New York: Harper \& Row.

Schweitzer, Albert (1929 [1923]), Civilization and Ethics, second edition translated by C.T. Campion. London: A \& C Black, Ltd.

Seuss, Dr. (1971), The Lorax. New York: Random House.

Sheth, Jagdish N. and Atal Parvatiyar (1995), “Ecological Imperatives and the Role of Marketing,” Chapter 1 in Michael J. Polonsky and Alma T. Mintu-Wimsatt, editors, Environmental Marketing: Strategies, Practice, Theory, and Research. Binghamton, NY: The Haworth Press.

Singer, Peter (1975), Animal Liberation: A New Ethics for Our Treatment of Animals. New York: Random House.

Sittler, Joseph (1954), “A Theology for Earth,” Christian Scholar 37 (September): 369374.

Smith, Adam (1937, orig. 1776), An Inquiry into the Nature and Causes of the Wealth of Nations. New York: Modern Library. (1976, orig. 1759), Theory of Moral Sentiments. Indianapolis: Liberty Classics.

Stanton, William J. (1981), Fundamentals of Marketing, sixth edition. New York: McGraw-Hill.

Taylor, Paul (1986), Respect for Nature. Princeton: Princeton University Press. 
Thoreau, Henry David (1854), Walden; or, Life in the Woods. Boston: J.R. Osgood.

Varner, Gary (2001), “Sentientism,” in A Companion to Environmental Philosophy, Dale Jamieson, editor. Malden, MA: Blackwell Publishers.

Wasserman, Edward and Thomas Zentall, editors (2006), Comparative Cognition: Experimental Explorations of Animal Intelligence. New York: Oxford University Press.

WCED (1987), Our Common Future. New York: Oxford University Press.

Westra, Laura and Thomas M. Robinson, editors (1997), The Greeks and the Environment. New York: Rowman and Littlefield Publishers.

White, E.B. (2006), Letters of E.B. White, revised edition, edited by Dorothy Lobrano Guth and Martha White. New York: Harper.

White Jr., Lynn (1967), “The Historical Roots of Our Ecological Crisis,” Science 157: 1203-1207.

Woods, Venessa (2010), Bonobo Handshake: A Memoir of Love and Adventure in the Congo. New York: Gotham Books.

\section{Further Reading}

\section{Environmental Ethics and Philosophy, and the General Reader}

Benson, John (2000), Environmental Ethics: An Introduction with Readings. New York: Routledge. (Also available as an e-book, 2013.)

Des Jardins, Joseph R. (2006), Environmental Ethics: An Introduction to Environmental Philosophy, fourth edition. Belmont, CA: Wadsworth Publishing. 
Gottfried, Robert R. (1995), Economics, Ecology, and the Roots of Western Faith: Perspectives from the Garden. Lanham, Maryland: Rowman \& Littlefield Publishers, Inc.

Hargrove, Eugene C. (1989), Foundations of Environmental Ethics. Englewood Cliffs, NJ: Prentice-Hall.

Kohák, Erazim (1999), The Green Halo: A Bird's Eye View of Ecological Ethics. Open Court Publishing Company. (Also available as an e-book, 2011.)

Newton, Lisa H. (2003), Ethics and Sustainability: Sustainable Development and the Moral Life. Upper Saddle River, NJ: Prentice Hall. (Also available as an audio book, 2004.)

Peterson, Anna L. (2001), Being Human: Ethics, Environment, and Our Place in the World. Berkeley, CA: University of California Press.

Rolston III, Holmes (1988), Environmental Ethics: Duties to and Values in the Natural World. Philadelphia: Temple University Press. (Also available as an e-book, 2012.)

Wenz, Peter S. (2001), Environmental Ethics Today. New York: Oxford University Press.

\section{Books of Readings}

Armstrong, Susan J. and Richard G. Botzler, editors (2004), Environmental Ethics: Divergence and Convergence, $3^{\text {rd }}$ edition. New York: McGraw-Hill. Clownew, David and Patricia Mosto, editors (2009), Earth Care: An Anthology in Environmental Ethics. Lanham, Maryland: Rowman \& Littlefield Publishers. 
Jamieson, Dale, editor (2001), A Companion to Environmental Philosophy. Malden, MA: Blackwell Publishers.

Kalof, Linda and Terre Satterfield, editors (2005), The Earthscan Reader in Environmental Values. London: Earthscan.

Keller, David R. and Frank B. Golley, editors (2000), The Philosophy of Ecology: From Science to Synthesis. Athens, GA: University of Georgia Press.

Pojman, Louis P. and Paul Pojman, editors (2008), Environmental Ethics: Readings in Theory and Application, fifth edition. Belmont, CA: Thomson|Wadsworth.

Sterba, James P., editor (1995), Earth Ethics: Introductory readings on Animal Rights and Environmental Ethics. Upper Saddle River, NJ: Prentice Hall ～[A second edition was published in 2000.]

Tucker, Mary Evelyn and John A. Grim, editors (1994), Worldviews and Ecology: Religion, Philosophy, and the Environment. Mary Knoll, New York: Orbis Books. Zimmerman, Michael E., J. Baird Callicott, Karen J. Warren, Irene Klaver and John Clark, editors (2005), Environmental Philosophy: From Animal Rights to Radical Ecology, fourth edition. Upper Saddle River, NJ: Pearson/Prentice Hall.

\section{Environmental Ethics for Engineering and Project Managers}

Gorman, Michael E., Matthew M. Mehalik, and Patricia H. Werhane (2000), Ethical and Environmental Challenges to Engineering. Englewood Cliffs, NJ: Prentice Hall.

Vesilind, P. Aarne and Alastair S. Gunn (1998), Engineering, Ethics, and the Environment, Cambridge: Cambridge University Press. 
Vromans, Kees, Rainer Paslack, Gamze Yücel Isildar, Rob de Vrind and Jürgen Walter Simon (2012), Environmental Ethics: An Introduction and Learning Guide. CITY: Greenleaf Publishing

\section{Environmental Ethics for Business}

DesJardins, Joseph R. (2007), Business, Ethics, and the Environment, Upper Saddle River, NJ: Pearson/Prentice Hall.

Newton, Lisa H. (2005), Business Ethics and the Natural Environment, Wiley-Blackwell. Westra, Laura and Patricia Werhane (eds), Business of Consumption: Environmental Ethics and the Global Economy. Lanham, Maryland: Rowman and Littlefield, 1998.

\section{Casebooks}

Derr, Patrick G. and Edward M. McNamara (2003), Case Studies in Environmental Ethics. Lanham, MA: Rowman \& Littlefield.

Gudorf, Christine E. and James E. Huchingson (2003), Boundaries: A Casebook in Environmental Ethics. Washington D.C.: Georgetown University Press.

Layzer, Judith A. (2006), The Environmental Case: Translating Values into Policy, second edition. Washington D.C.: CQ Press.

Newton, Lisa H. and Catherine K. Dillingham (1994), Watersheds: Classic Cases in Environmental Ethics. Belmont, CA: Wadsworth.

Newton, Lisa H. and Catherine K. Dillingham (1996), Watersheds 2: Ten Cases in Environmental Ethics. Wadsworth Publishing Co. 
Newton, Lisa H. and Catherine K. Dillingham (2001), Watersheds 3: Ten Cases in Environmental Ethics. Wadsworth Publishing Co.

Newton, Lisa H., Catherine K. Dillingham and Joanne H. Choly (2005), Watersheds 4: Ten Cases in Environmental Ethics. Thomson/Wadsworth Publishing Co.

\section{Books with a Religious or Spiritual Orientation}

Gardner, Gary T. (2006), Inspiring Progress: Religions' Contributions to Sustainable Development. New York: W.W. Norton.

Gardner, Gary T. (2006), Inspiring Progress: Religions’ Contributions to Sustainable Development. New York: W. W. Norton \& Company.

Gottlieb, Roger S. (2006), A Greener Faith: Religious Environmentalism and Our Planet’s Future. NY: Oxford University Press.

Gottlieb, Roger S., editor (2006), The Oxford Handbook of Religion and Ecology. New York: Oxford University Press.

Hessel, Dieter and Rosemary Radford Ruether, editors (2000), Christianity and Ecology: Seeking the Well-Being of Earth and Humans. Cambridge, MA: Harvard University Press.

Martin-Schramm, James B. and Robert L. Stivers (2003), Christian Environmental Ethics: A Case Method Approach. Mary Knoll, New York: Orbis Books. Spring, David and Eileen Spring, editors (1974), Ecology and Religion in History. New York: Harper and Row. 


\section{Aldo Leopold}

Callicott, J. Baird (1979), “Elements of an Environmental Ethic: Moral Considerability and the Biotic Community,” Environmental Ethics 1 (Spring): 71-81.

Callicott, J. Baird (1980), “Animal Liberation: A Triangular Affair,” Environmental Ethics 2 (Winter): 71-81.

Callicott, J. Baird (1985), “The Metaphysical Implications of Ecology,” Environmental Ethics 8 (Winter): 301-316.

Callicott, J. Baird (1987). The Conceptual Foundations of the Land Ethic,” in Callicott, J. Baird, editor, Companion to A Sand County Almanac: Interpretive and Critical Essays. Madison, Wisconsin: University of Wisconsin Press.

Callicott, J. Baird (1989), In Defense of the Land Ethic. Albany, New York: State University of New York Press. (2001), “The Land Ethic,” in A Companion to Environmental Philosophy, edited by Dale Jamieson. Malden, MA: Blackwell Publishers. (2005). Turning the Whole Soul: The Educational Dialectic of A Sand County Almanac. Worldviews: Environment, Culture, Religion, 9, (3): 365-384. Marietta, Don E. (1979), “The Interrelationship of Ecological Science and Environmental Ethics,” Environmental Ethics 1 (Fall): 195-207. 